www.jmscr.igmpublication.org

Impact Factor (SJIF): 6.379

Index Copernicus Value: 79.54

ISSN (e)-2347-176x ISSN (p) 2455-0450

crossrefDOI: https://dx.doi.org/10.18535/jmscr/v6i9.161

Journal Of Medical Science And Clinical Research

\title{
Ocular Surface Manifestations in ICU Patients
}

Authors

\section{Dr Sankalpa K C ${ }^{1}$, Dr Shanthala Arun Kumar ${ }^{2}$, Dr Ajay .S.Hatti ${ }^{3}$}

${ }^{1}$ Post Graduate, S.S. Institute of Medical Sciences and Research Centre, Davangere, Karnataka, India

Email: sankalpa1590@gmail.com

${ }^{2}$ Professor \& HOD, S.S. Institute of Medical Sciences and Research Centre, Davangere, Karnataka, India

${ }^{3}$ Professor, S.S. Institute of Medical Sciences and Research Centre, Davangere, Karnataka, India

\begin{abstract}
Background: ocular manifestations are most common in icu patients because of impaired ocular protective mechanisms

Aims and Objectives: 1) To study the ocular surface manifestations in ICU.2) To look for the association between eye lid position and ocular surface manifestations.

Materials and Methods: prospective hospital based study among 96 patients hospitalized in ICU. Anterior segment examination is done by torch light. Eye lid position and keratopathy noted.

Conclusion: The study found out the correlation between different eyelid position and the ocular surface disorder with significant $p$ value.13 patients among 59 having different lid position other than lids apposed developed ocular surface manifestations.

Keywords: correlation, eye lid position, ocular surface manifestations.
\end{abstract}

\section{Introduction}

Ocular surface disorders are frequently encountered in patients in ICU'S. Patients in intensive care units have impaired ocular protective mechanisms resulting in high risk of developing eye complications $^{[1] .}$ Ventilated patients in ICU often develop exposure keratopathy. This predisposes to the development of bacterial keratitis, with a high risk of perforation.

\section{Aims and Objectives}

1. To study the ocular surface manifestations in ICU

2. To look for the association between eye lid position and ocular surface manifestations.

\section{Method of Study}

We conducted a Prospective hospital based study among patients who were treated in ICU, SSIMS \& RC, Davangere, and Karnataka

A total of 96 patients are included in the study.

Consecutive patients who meet the inclusion criteria were considered in the study by convenient sampling.

\section{Inclusion Criteria}

- Patients on ventilator

- Unconscious patients

\section{Exclusion Criteria}

- Patients with eye lid \& facial injury.

The eyes of all patients admitted to the ICU for whom ophthalmology reference was given is assessed at first visit and followed up whenever 
required. Informed consent was obtained from relatives. Anterior segment is examined with the use of a bright hand held torch .The eyelid position and keratopathy are noted and categorised as shown in table $1 \& 2$.

Most ICU patients were sedated to some degree. The depth of sedation was assessed according to the Ramsay sedation scale ${ }^{[2]} \&$ we have taken sedation score of 6 .

Fluorescein staining, Conjunctival swabs, corneal scrapping was taken whenever required.

Table 1 eye lid position grading

\begin{tabular}{|l|l|}
\hline Grade 1 & Lids apposed \\
\hline Grade 2 & Conjunctiva exposed \\
\hline Grade 3 & Limbus exposed \\
\hline
\end{tabular}

Table 2 ocular surface disease category

\begin{tabular}{|l|l|}
\hline 1 & $\begin{array}{l}\text { Punctate epithelial erosions (PEEs) involving } \\
\text { the inferior third of the cornea }\end{array}$ \\
\hline 2 & $\begin{array}{l}\text { PEEs involving more than the inferior third of } \\
\text { the corneal surface }\end{array}$ \\
\hline 3 & Macroepithelial defect (MED) \\
\hline 4 & $\begin{array}{l}\text { Stromal whitening in the presence of epithelial } \\
\text { defect (SWED) }\end{array}$ \\
\hline 5 & Stromal scar \\
\hline 6 & Microbial keratitis \\
\hline
\end{tabular}

\section{Results}

\begin{tabular}{|l|c|c|c|c|}
\hline \multirow{2}{*}{ Eyelid position } & \multicolumn{2}{|c|}{$\begin{array}{c}\text { Ocular surface } \\
\text { manifestations }\end{array}$} & \multirow{2}{*}{ Total } & \multirow{2}{*}{ value } \\
\cline { 2 - 3 } & Absent & Present & & \\
\hline $\begin{array}{l}\text { Conjunctiva } \\
\text { exposed }\end{array}$ & 50 & 7 & 57 & \\
\cline { 1 - 4 } $\begin{array}{l}\text { incomplete lid } \\
\text { closure }\end{array}$ & 10 & 2 & 12 & \\
\hline lids opposed & 23 & 2 & 25 & \multirow{2}{*}{0.003} \\
\hline limbus exposed & 0 & 2 & 2 & \multicolumn{2}{|c}{} \\
\hline \multicolumn{1}{|c|}{ Total } & 83 & 13 & 96 & \\
\hline
\end{tabular}

\begin{tabular}{|l|c|c|c|c|}
\hline Eyelid position & \multicolumn{2}{|c|}{$\begin{array}{l}\text { Ocular surface } \\
\text { manifestations }\end{array}$} & Total & p value \\
\cline { 2 - 3 } & Absent & Present & & \\
\hline $\begin{array}{l}\text { Other lid } \\
\text { positions }\end{array}$ & 59 & 13 & 72 & \\
\hline Lids opposed & 24 & 0 & 24 & \multirow{2}{*}{0.025} \\
\hline Total & 83 & 13 & 96 & \\
\hline
\end{tabular}

Out of 96 patients, ocular surface manifestations were present in 13 patients, among which 72 had abnormal lid position \& 24 had lids opposed. The study found the correlation between abnormal lid position and ocular surface manifestations.

\section{Discussion}

Eye lid provides the normal defensive mechanism of ocular surface by acting as a barrier, along with the tear film.From our study it is clear that the position of the eyelids is associated with the development of ocular surface disease from punctate epithelial erosion to microbial keratitis. Depth of sedation also decreases the blink reflex, which increases the risk of exposurekeratopathy.

Previous study showed that duration of sedation and ventilation as well as severity of illness significantly influences the development of OSD not the eye lid position which is contradictory to our study. [3]

Old studies showed that assessment of lid position in ICU patients is the single most important observation to be carried out which is similar to our results. ${ }^{[4]}$

Other studies showed different ocular surface manifestations and proved that they are treated successfully with topical antibiotics. ${ }^{[5]}$

\section{Conclusion}

As ICU patients are more susceptible to develop ocular infections proper ophthalmological intervention like early diagnosis and treatment of ocular surface disorders is needed.

Eye lid position is the best indicator to influence the ocular surface disorders.

\section{References}

1. S. Sivasankar, S. Jasper, S. Simon, P. Jacob, G. John, R. Raju.Eye care in ICU. Indian J Crit Care Med 2006; 10(1):11-14.

2. Liu LL, Gropper MA. Postoperative analgesia and sedation in the adult intensive care unit. A guide to drug selection. Drugs, 2003; 63(8):755-67.

3. I Desalu, F Akinsola, O Adekola, O Akinbami, O Kushimo, AAdefule-Ositelu. Ocular Surface Disorders In Intensive Care Unit Patients In A Sub-Saharan Teaching Hospital .IJEICM 2007; 11: 1-8.

4. Franco Mercieca, Palanisamy Suresh, Andrew Morton and Alan Tullo. Ocular 
surface disease in intensive care unit patients. Eye 1999; 13: 231-236.

5. Tuba Berra Saritas, Banu Bozkurt, Baris Simsek, Zeynep Cakmak, Mehmet Ozdemir, and Alper Yosunkaya. Ocular Surface Disorders in Intensive Care Unit Patients. Sci World J .2013:1-8. 